\title{
Transformation of an Industrial Brownfield into an Ecological Buffer for Michigan's Only Ramsar Wetland of International Importance
}

\author{
John H. Hartig ${ }^{1, *}$, Allison Krueger ${ }^{1}$, Kelly Rice ${ }^{2}$, Steven F. Niswander ${ }^{3}$, Burke Jenkins ${ }^{4}$ \\ and Greg Norwood ${ }^{1}$
}

1 Detroit River International Wildlife Refuge, U.S. Fish and Wildlife Service, 9311 Groh Road, Grosse Ile, Michigan 48138, USA; E-Mails:krueger.ali@gmail.com (A.K.);

greg_norwood@fws.gov (G.N.)

2 Cardno JFNew, 11181 Marwill Avenue, West Olive, Michigan 49460, USA;

E-Mail: kelly.rice@cardno.com

3 Niswander Environmental, LLC, 10524 Grand River Avenue, Suite 103, Brighton,

Michigan 48116, USA; E-Mail:sniswan@niswander-env.com

4 Hamilton Anderson Associates, 1435 Randolph, Suite 200, Detroit, Michigan 48226, USA;

E-Mail:bjenkins@hamilton-anderson.com

* Author to whom correspondence should be addressed; E-Mail: john_hartig@fws.gov;

Tel.: +1-734-692-7608; Fax: +1-734-692-7603.

Received: 29 March 2012; in revised form: 24 April 2012 / Accepted: 9 May 2012 /

Published: 18 May 2012

\begin{abstract}
The Detroit River International Wildlife Refuge spans $77 \mathrm{~km}$ along the Detroit River and western Lake Erie, and is the only unit of the National Wildlife Refuge System that is international. A key unit of the refuge is the 166-ha Humbug Marsh that represents the last kilometer of natural shoreline on the U.S. mainland of the river and Michigan's only "Wetland of International Importance" designated under the 1971 International Ramsar Convention. Adjacent to Humbug Marsh is an 18-ha former industrial manufacturing site (now called the Refuge Gateway) that is being remediated and restored as an ecological buffer for Humbug Marsh and the future home of the refuge's visitor center. Restoration and redevelopment activities have included: cleanup and capping of contaminated lands; daylighting a creek (i.e., deliberately exposing the flow of a creek that was historically placed underground in a culvert) and constructing a retention pond and emergent wetland to treat storm water prior to discharge to the Detroit River; restoring
\end{abstract}


coastal wetland, riparian buffer, and upland habitats; and constructing two roads, hiking/biking trails, and a kayak/canoe landing to offer wildlife-compatible public uses that allow visitors to experience this internationally-recognized natural resource. This project has been described as transformational for the region by restoring an industrial brownfield into high quality wildlife habitat that expands the ecological buffer of a Ramsar site. Specific restoration targets for the site include: achieving a net gain of 6.5 ha of wetlands in a river that has lost $97 \%$ of its coastal wetlands to development; restoring 10.1 ha of upland buffer habitat; treating invasive Phragmites along $4 \mathrm{~km}$ of shoreline; and treatment of invasive plant species in 20.2 ha of upland habitats in Humbug Marsh. Further, the Refuge Gateway is being restored as a model of environmental sustainability for nearly seven million residents within a 45-minute drive. Key lessons learned include: reach broad-based agreement on a sustainability vision; identify and involve a key champion; establish core project delivery team; ensure up-front involvement of regulatory agencies; recruit and meaningfully involve many partners; expect the unexpected; practice adaptive management; place a priority on sound science-based decision making; ensure decision-making transparency; measure and celebrate successes, including benefits; and place a high priority on education and outreach.

Keywords: brownfield cleanup; habitat restoration; "Wetland of International Importance"

\section{Introduction}

The Detroit River International Wildlife Refuge (DRIWR) spans $77 \mathrm{~km}$ along the lower Detroit River and western Lake Erie, and is a shared resource between Canada and the United States [1]. The Detroit River alone has 23 islands, numerous wetlands and shoals, and critical stopover habitats for birds and spawning and nursery grounds for fishes. As a result, this ecological corridor supports exceptional biodiversity (e.g., 117 species of fish, over 300 species of birds). This exceptional biodiversity and the unique habitats that support it have been recognized in the North American Waterfowl Management Plan, the United Nations Convention on Biological Diversity, the Western Hemispheric Shorebird Reserve Network, and the Biodiversity Investment Area program of Environment Canada and U.S. Environmental Protection Agency [2].

One of the key units of the DRIWR is the 166-ha Humbug Marsh (Figure 1). Humbug Marsh represents a significant portion of the last unaltered wetlands in the Detroit River corridor and the last kilometer of natural shoreline on the river's U.S. mainland. It is Michigan's only "Wetland of International Importance" designated under the 1971 International Ramsar Convention [3]. Located adjacent to Humbug Marsh is an 18-ha industrial brownfield site that is being cleaned up and restored as the Refuge Gateway. This site will expand the ecological buffer for Humbug Marsh, the gateway to the DRIWR and the future home of the refuge's visitor center. This paper will: describe how a multi-stakeholder process focused on sustainability is transforming this industrial brownfield into the Refuge Gateway and expanding the ecological buffer of a "Wetland of International Importance;" document results achieved; and share lessons learned. 
Figure 1. Map showing the location of Humbug Marsh and the Refuge Gateway along Detroit River.

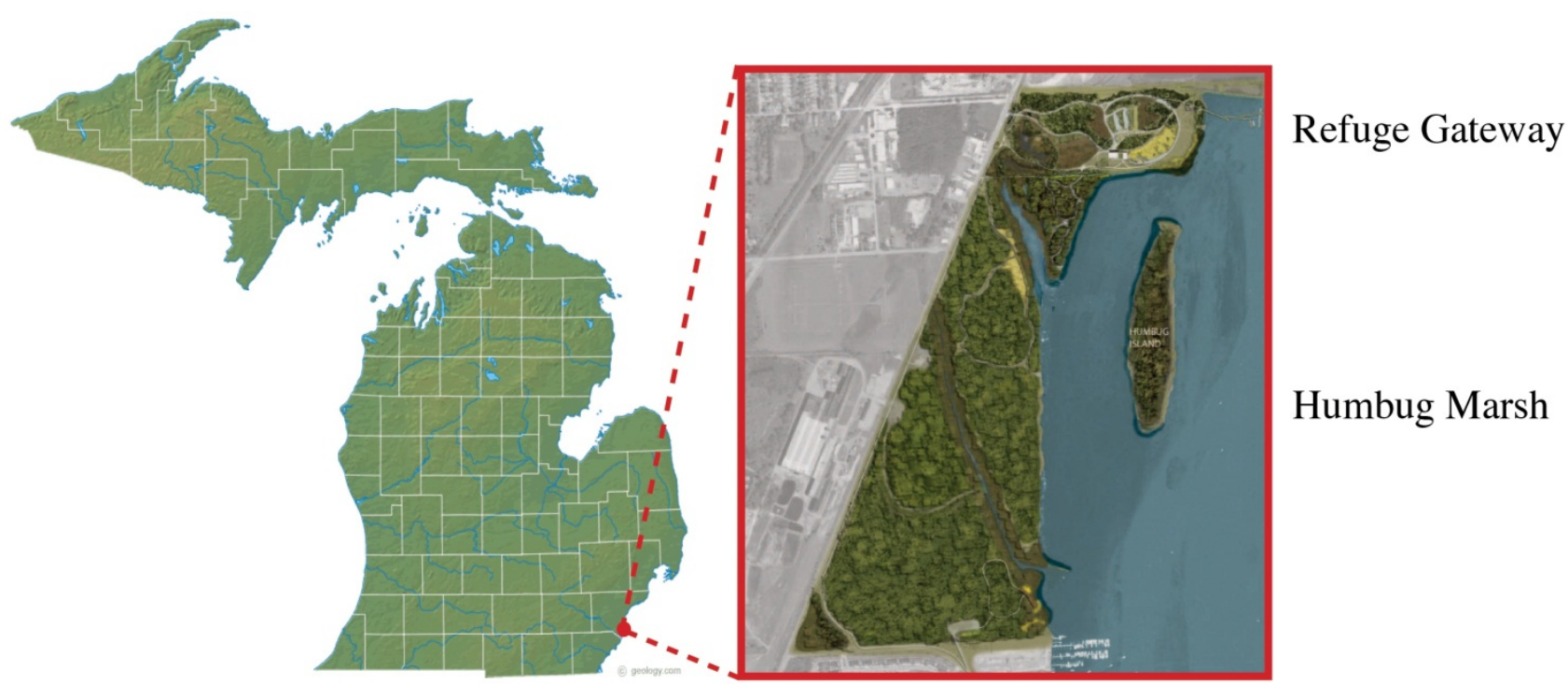

\subsection{History of the Refuge}

In 2000, a group of scientists and managers were charged with defining a desired future state for the Detroit River ecosystem by then Canadian Deputy Prime Minister Herb Grey and U.S. Congressman John Dingell. This vision was articulated in a consensus document titled "A Conservation Vision for the Lower Detroit River Ecosystem" [4]. All U.S. and Canadian participants agreed in 2001 to the following vision statement:

In ten years the lower Detroit River ecosystem will be an international conservation region where the health and diversity of wildlife and fish are sustained through protection of existing significant habitats and rehabilitation of degraded ones, and where the resulting ecological, recreational, economic, educational, and "quality of life" benefits are sustained for present and future generations.

U.S. Congressman John Dingell then introduced legislation in 2001, founded on the conservation vision, to establish the DRIWR. It was signed into law by the President of the United States on December 21, 2001, becoming part of the U.S. National Wildlife Refuge System that includes over 550 refuges and over 60 million ha of land. A wildlife refuge is a geographical area where waters and lands are set aside to conserve ecosystems. Canada responded by using a number of existing Canadian laws to work in a similar fashion. All U.S. and Canadian agencies agreed with the concept of the international wildlife refuge and pledged to work collaboratively to achieve the conservation vision.

The U.S. Fish and Wildlife Service then developed a Comprehensive Conservation Plan for the DRIWR with broad stakeholder involvement, including participation from Canada [1]. This plan adopted of the following vision statement:

The Detroit River International Wildlife Refuge, including the Detroit River and western Lake Erie basin, will be a conservation region where a clean environment fosters the health and diversity of wildlife, fish, and plant resources through protection, creation of 
new habitats, management, and restoration of natural communities and habitats on public and private lands. Through effective management and partnering, the Refuge will provide outstanding opportunities for "quality of life" benefits such as hunting, fishing, wildlife observation and environmental education, as well as ecological, economic, and cultural benefits, for present and future generations.

In 2005, the U.S. Fish and Wildlife Service established a Friends' Group (i.e., an independent nongovernmental organization) called the International Wildlife Refuge Alliance to build the capacity of the refuge to work in partnerships and to advance its goals. Specifically, the International Wildlife Refuge Alliance's mission is:

to support the first International Wildlife Refuge in North America by working through partnerships to protect, conserve and manage the refuge's wildlife and habitats, and to create exceptional conservation, recreational and educational experiences to develop the next generation of conservation stewards.

Through binational collaboration an international wildlife refuge had been created, founded on the goals of conservation and sustainability. All stakeholders agreed to work through partnerships at all levels to move forward together toward this common vision.

\subsection{Industrial History of the Refuge Gateway}

In 1946, Chrysler Corporation applied to the City of Trenton, Michigan for a building permit to construct its first building on what was then 17.8 ha of vacant land and adjacent water (Table 1). Additional buildings were constructed from 1952 through 1973. It was operated by Chrysler Corporation as a manufacturing facility for brake pad adhesives for automobiles, blended oils, paints, sealers, powdered metal parts, asbestos brake pads, and phenolic brake pistons (Figure 2).

Figure 2. Aerial photograph of the Chrysler Manufacturing Facility in Trenton, Michigan, 1967.

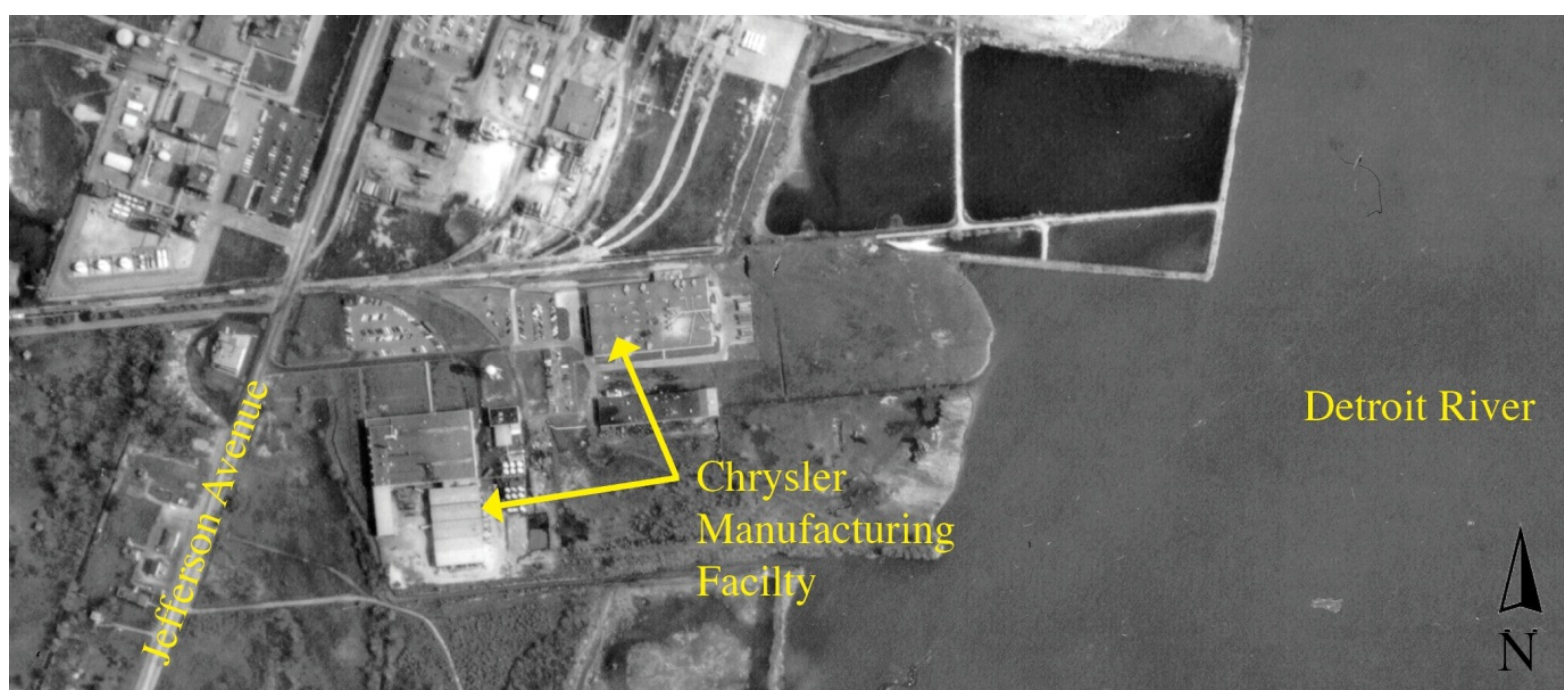


Table 1. Site history of Wayne County's Refuge Gateway in Trenton, Michigan.

\begin{tabular}{|c|c|}
\hline Date & Activity \\
\hline $1946-1990$ & $\begin{array}{l}\text { - Chrysler operated this facility as an automotive component manufacturing plant, including } \\
\text { production of brakes, associated adhesives, oils, and sealers }\end{array}$ \\
\hline 1990 & - Chrysler facility closed and remediated to industrial standards \\
\hline 1994 & - Consent Decree signed, with restrictive covenants \\
\hline 2001 & - Detroit River International Wildlife Refuge Establishment Act signed into law \\
\hline 2002 & $\begin{array}{l}\text { - Chrysler property purchased by Wayne County with National Oceanic and Atmospheric } \\
\text { Administration funding to become the Refuge Gateway for the Detroit River International } \\
\text { Wildlife Refuge } \\
\text { - Consent Decree modified to allow for the construction of a Visitor Center on site for the } \\
\text { Detroit River International Wildlife Refuge }\end{array}$ \\
\hline 2004 & $\begin{array}{l}\text { - Wayne County completes site Master Plan for Refuge Gateway, with input from U.S. Fish } \\
\text { and Wildlife Service and other partners }\end{array}$ \\
\hline 2005 & $\begin{array}{l}\text { - Comprehensive Conservation Plan completed and approved by U.S. Fish and Wildlife } \\
\text { Service, identifying Wayne County's Refuge Gateway as the proposed site of a future } \\
\text { Refuge headquarters and visitor center }\end{array}$ \\
\hline 2006 & $\begin{array}{l}\text { - Schematic Plan for Refuge Gateway completed, providing more detailed information for } \\
\text { restoration efforts and visitor center design, and integrating the Refuge Gateway property } \\
\text { with Humbug Marsh Unit of the U.S. Fish and Wildlife Service }\end{array}$ \\
\hline 2006-2007 & $\begin{array}{l}\text { - Kresge Foundation grant for planning for green site features at Refuge Gateway and } \\
\text { LEED-certified visitor center }\end{array}$ \\
\hline 2007 & $\begin{array}{l}\text { - State of Michigan unveils historical marker at Refuge Gateway, identifying it as the first } \\
\text { location on the Michigan Conservation Trail that commemorates and promotes knowledge } \\
\text { of conservation history in Michigan }\end{array}$ \\
\hline 2008 & $\begin{array}{l}\text { - Trails, environmental education shelter, and wetland boardwalk constructed in Humbug } \\
\text { Marsh Unit and pedestrian stream crossing completed, linking Humbug Marsh Unit and } \\
\text { Refuge Gateway }\end{array}$ \\
\hline 2009 & $\begin{array}{l}\text { - Daylighting Monguagon Creek completed and capping and final grade achieved on } 40 \% \text { of } \\
\text { the Refuge Gateway } \\
\text { - First loop of access road completed at the Refuge Gateway }\end{array}$ \\
\hline 2010 & $\begin{array}{l}\text { - Perimeter greenway trail completed at Humbug Marsh, linking Refuge's Lake Erie } \\
\text { Metropark Unit with Humbug Marsh Unit and the Refuge Gateway } \\
\text { - Entry garden completed at Refuge Gateway by volunteers from Ford Motor Company, } \\
\text { Grosse Ile Garden Club, and International Wildlife Refuge Alliance }\end{array}$ \\
\hline 2011 & $\begin{array}{l}\text { - Construction of a natural shoreline at Refuge Gateway and final grade achieved on another } \\
30 \% \text { of the Refuge Gateway } \\
\text { - Construction of a shoreline access road to provide accessibility for the future boat dock } \\
\text { and fishing pier } \\
\text { - Creation of a kayak landing }\end{array}$ \\
\hline 2012 & $\begin{array}{l}\text { - Complete all capping on site, consistent with Master Plan } \\
\text { - Achieve final grade on remaining } 30 \% \text { of the Refuge Gateway consistent with Master Plan } \\
\text { - Complete plantings consistent with habitat elements identified in the Master Plan }\end{array}$ \\
\hline
\end{tabular}


Historical aerial photographs show that fill was placed on the eastern portion of the property from the 1940 s to 1967 . This literally filled approximately 4.5 ha of wetlands and extended the upland portion of the property eastward into the Detroit River approximately $0.25 \mathrm{~km}$.

This Chrysler Plant in Trenton was deactivated in 1990 and underwent removal of all above-ground structures. In 1994, Chrysler Corporation and the Michigan Department of Natural Resources entered into a Consent Decree. The Consent Decree is a legally binding document describing Chrysler Corporation's remedial responsibilities, the extent of continuing liability for this site, and long-term due care obligations [5]. On site remedial activities included removal and isolation of both inorganic (i.e., asbestos, arsenic, barium, cadmium, lead, cyanide and thallium) and organic (i.e., benzene, chlorobenzene, methylene chloride, toluene, vinyl chloride and xylene) contaminants.

Essentially, the site was cleaned up at a cost of approximately $\$ 12$ million to meet State of Michigan standards for industrial and commercial use. Pursuant to the Consent Decree, restrictive covenants were placed on five areas of the site totaling approximately 6.2 ha. These restrictive covenants limit future activities and use of the five areas due to subsurface contamination. For example, there can be no digging in the capped areas that might release contaminants or exacerbate environmental problems. Restrictive covenants remain in effect in the transfer of the property to any future owner. Therefore, Wayne County, the current owner of the Refuge Gateway and partner on the restoration effort, is required to follow these restrictions determined in the Consent Decree. Specific restrictions placed on these five areas of the property included:

- Any soils removed from the site must be tested for contaminants;

- On-site groundwater may not be used as drinking water;

- Uses of the property must be restricted, consistent with the remediation performed (future uses may require reevaluation by the State of Michigan);

- The State of Michigan must have access to determine compliance, including the rights to take samples, inspect records, and inspect remedial actions; and

- In five restricted areas, future owners must restrict activities that might interfere with a response activity, operation and maintenance, monitoring, or other measures necessary to assure the effectiveness and integrity of the remedial actions.

In addition, there is a due care plan for the site that helps ensure that all restrictions and measures in the Consent Decree are followed in perpetuity, and that any future uses do not exasperate residual environmental contamination.

\subsection{Preservation of Humbug Marsh}

In the mid-1990s, a developer purchased Humbug Marsh with the intent of building a subdivision, a marina, a golf course, a bridge to Humbug Island to accommodate homes, and more. The proposed development required several permits and requisite public hearings. The first public hearing was held at Gibraltar Carlson High School in September 1998 and attracted nearly 1,000 people [6]. People from all over Michigan attended, creating traffic jams and causing the fire marshal to lock the doors of the public hearing to prevent a larger crowd. The issue at hand was residential development of the last kilometer of natural shoreline on the U.S. mainland of the Detroit River-Humbug Marsh. 
The vast majority of these citizens strongly opposed the development and was in favor of preserving the rich and diverse coastline that was part of their home and heritage. Indeed, citizens and grassroots organizations banded together for nearly ten years in a campaign to preserve Humbug Marsh. This tremendous public support was a key catalyst in establishing the DRIWR. The people spoke out in opposition, the permits were not issued, and eventually Humbug Marsh was purchased in 2004 for the DRIWR. Humbug Marsh now is part of the National Wildlife Refuge System and is protected for wildlife and for people to enjoy through wildlife-compatible public uses. Today, it stands as a site of great determination and pride by those in the region.

Following the preservation of Humbug Marsh in 2004, the Michigan Department of Natural Resources and Environment and the U.S. Fish and Wildlife Service spent nearly three years compiling scientific data on Humbug Marsh that was used as the rationale for obtaining a "Wetland of International Importance" designation under the international Ramsar Convention. In 2010, Humbug Marsh was designated as a Ramsar Convention "Wetland of International Importance." There are 1,900 such Ramsar designations worldwide, 29 in the United States, and only one in Michigan-Humbug Marsh. The Ramsar Convention is an international treaty that was signed in Ramsar, Iran in 1971 that provides a framework for voluntary international protection of wetlands [3]. Countries signing the treaty must demonstrate their commitment to the conservation and wise use of wetlands as a contribution toward sustainable development throughout the world. Humbug Marsh is considered an internationally important wetland because of its ecological importance in the Detroit River corridor and the Great Lakes Basin Ecosystem (Table 2). It serves as vital habitat for 51 species of fish, 90 species of plants, 154 species of birds, seven species of reptiles and amphibians, and 37 species of dragonflies and damselflies.

Table 2. Ramsar criteria and rationale for designating Humbug Marsh a "Wetland of International Importance" [7].

\begin{tabular}{|c|c|}
\hline Ramsar Criterion & Rationale \\
\hline $\begin{array}{l}\text { Importance to Threatened, } \\
\text { Endangered and Vulnerable } \\
\text { Species, and Ecological } \\
\text { Communities }\end{array}$ & $\begin{array}{l}\text { The wetlands within Humbug Marsh are classified as Great Lakes marsh, a } \\
\text { natural community that has been ranked as a globally imperiled community by } \\
\text { the Michigan Natural Features Inventory. As the shorelines of the Great Lakes } \\
\text { were developed for industrial, commercial, residential, and recreational use, the } \\
\text { marsh habitat essential for many Great Lakes species rapidly declined. }\end{array}$ \\
\hline $\begin{array}{l}\text { Importance for Maintaining } \\
\text { Biological Diversity }\end{array}$ & $\begin{array}{l}\text { Because Humbug Marsh represents a significant portion of the last unaltered } \\
\text { wetlands in the Detroit River corridor and the last mile of natural shoreline on the } \\
\text { river's U.S. mainland, it serves as a vital habitat for a large variety of endemic } \\
\text { fish, birds, and plants that are regionally rare and may otherwise be extirpated } \\
\text { from the area. Surveys have documented } 51 \text { species of native fish, over } 90 \text { native } \\
\text { plant species, at least a } 154 \text { native bird species from } 39 \text { different families, more } \\
\text { than } 25 \text { species of reptiles and amphibians, and } 12 \text { species of damselflies and } \\
25 \text { species of dragonflies. }\end{array}$ \\
\hline
\end{tabular}


Table 2. Cont.

\begin{tabular}{|c|c|}
\hline Ramsar Criterion & Rationale \\
\hline $\begin{array}{l}\text { Importance as Habitat for } \\
\text { Plants or Animals in } \\
\text { Critical Stages of their } \\
\text { Lifecycles }\end{array}$ & $\begin{array}{l}\text { Humbug Marsh and the lower Detroit River are located at the intersection of two } \\
\text { important migratory bird flyways (i.e., Atlantic and Mississippi Flyways), } \\
\text { making it prime stopover habitat during fall and spring migrations. Humbug } \\
\text { Marsh is also a critical corridor along the Detroit River for herpetofauna and } \\
\text { serves as an important breeding, nesting, and developmental site for a number of } \\
\text { amphibian and reptile species. }\end{array}$ \\
\hline $\begin{array}{l}\text { Importance to Indigenous } \\
\text { Fish Biodiversity }\end{array}$ & $\begin{array}{l}\text { The variety of habitats existing within Humbug Marsh allows fish with diverse } \\
\text { life histories to thrive. In a fish survey that included Humbug Marsh and } \\
\text { surrounding areas, } 51 \text { indigenous fish species were identified, representing } \\
15 \text { different families. }\end{array}$ \\
\hline $\begin{array}{l}\text { Importance as a Food } \\
\text { Source, Spawning, } \\
\text { Nursery or Migration Area } \\
\text { on which Fish Depend on }\end{array}$ & $\begin{array}{l}\text { Each year, over } 3 \text { million walleye (Stizostedion vitreum), approximately } 10 \% \text { of } \\
\text { the population of Lake Erie, run the Detroit River. Once the walleye spawn on } \\
\text { rocky substrate within the river, larval fish travel to the marsh and use it as an } \\
\text { essential nursery habitat. The wetlands provide spawning and nursery areas for } \\
\text { yellow perch (Perca flavescens), muskellunge (Esox masquinongy), brown } \\
\text { bullhead (Ameiurus nebulosus) and many other fishes. In addition, Humbug } \\
\text { Marsh serves as one of the only remaining spawning and nursery areas for forage } \\
\text { fishes, which rely on the significant cover of emergent and submergent } \\
\text { vegetation for their survival. }\end{array}$ \\
\hline
\end{tabular}

\section{Transformation of the Refuge Gateway}

Following the establishment of the DRIWR in 2001 and during the public campaign to preserve Humbug Marsh, the 17.8 ha, former Chrysler property in Trenton was purchased to become the Refuge Gateway. The Refuge Gateway was given its name to become the gateway to the international wildlife refuge and to become the future home of the refuge's visitor center. From the outset, U.S. Congressman John Dingell has served as the project champion, opening doors to key decisionmakers, bringing in new partners, and building the capacity for growing and managing the DRIWR.

In 2003, Wayne County initiated a master planning process for the Refuge Gateway that was completed in 2004 (Figure 3). The goal of the master plan was to be a model of sustainable redevelopment by providing a blueprint for the cleanup and restoration work necessary to establish the site as an ecological buffer for Humbug Marsh and to encourage public uses. Everything people would see and do at the Refuge Gateway would teach them how to live sustainably. Further, the site would be integrated with Humbug Marsh in a fashion that would help Wayne County, the U.S. Fish and Wildlife Service, and other partners teach the next generation of conservationists and sustainability entrepreneurs. 
Figure 3. Refuge Gateway Master Plan adopted by Wayne County and partners in 2004 [8].

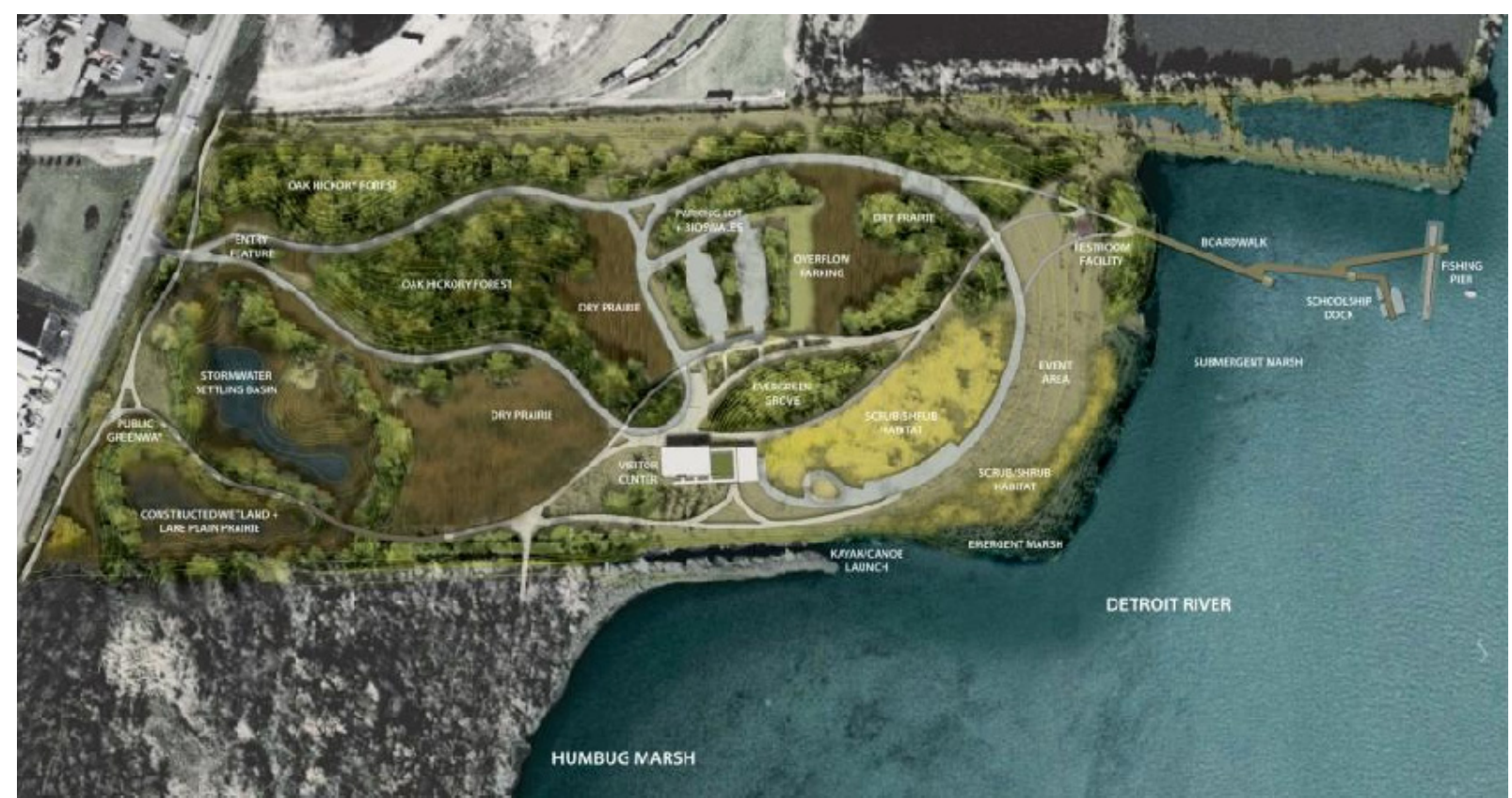

\subsection{Environmental Education and a Visitor Center}

This mission of teaching the next generation of conservationists and sustainability entrepreneurs will be accomplished by offering exceptional environmental education, interpretation, and outdoor recreation in an ecosystem that has been recognized for its biodiversity in the North American Waterfowl Management Plan, the United Nations Convention on Biological Diversity, the Western Hemispheric Shorebird Reserve Network, the Biodiversity Investment Area Program of Environment Canada and U.S. Environmental Protection Agency, and the international Ramsar Convention on Wetlands. Further, restoration activities would serve as "teachable moments" in support of the educational mission.

The overall project goal was to clean up the site for public use as the Refuge Gateway that will include a visitor center and to restore habitats (e.g., submergent, emergent, and wet meadow zones) that will expand the ecological buffer of Humbug Marsh. Specific restoration targets for the site included: restoring 6.5 ha of wetlands; restoring 10.1 ha of upland buffer habitat; treating invasive Phragmites along $4 \mathrm{~km}$ of shoreline; and treatment of invasive plant species in 20.2 ha of upland habitats in Humbug Marsh. Therefore, this project is consistent with key tenets of ecological restoration that call for protecting habitats of exceptional biodiversity (e.g., Humbug Marsh Unit), expanding their ecological buffers (e.g., restoring fish and wildlife habitat at the adjacent Refuge Gateway), and then linking with other high quality habitats.

In 2005, the Refuge Gateway was identified in the Refuge's Comprehensive Conservation Plan as the future home of the visitor center and a schematic plan was completed in 2006. Additional site planning for green site features and Leadership in Energy and Environmental Design (LEED) certification was then undertaken in 2005-2007. 


\subsection{Daylighting Monguagon Creek}

As part of the effort to showcase sustainable practices, the Monguagon Creek was unearthed from an underground pipe at the Refuge Gateway and daylighted in 2009. Historically, storm water from a small watershed in the city of Trenton was transported to the Detroit River through a concrete underground pipe. Through this Monguagon Creek Daylighting and Wetland Restoration project, 2.4 ha of wetlands were created in an area that has lost $97 \%$ of its coastal wetlands to anthropogenic development (Figure $4 \mathrm{a}$ and $\mathrm{b}$ ). The project included constructing a storm water treatment basin and an emergent wetland as a two-step process of naturally treating urban storm water before entering the Detroit River. The retention pond accomplishes settling of solids and the emergent wetland promotes nutrient uptake. A pump installed in the wetland allows for the movement of water from the constructed wetland into the adjacent Monguagon Delta of Humbug Marsh. Moving water into Humbug Marsh can be used as a management tool for decreasing the density of invasive Phragmites in the Monguagon Delta after Phragmites has been treated and removed, thereby promoting greater native species diversity from the existing seed bank. Additionally, the delta provides 1.4 ha of established emergent wetland for additional storm water treatment. Other project benefits included wildlife habitat creation and opportunities for hands-on environmental education and natural resource interpretation. Also completed in 2009 were the first access road and some capping, and achievement of final grade (as called for in the master plan) on the western third of the Refuge Gateway property.

Figure 4. Photographs of the Refuge Gateway as a brownfield site prior to daylighting Monguagon Creek (a) and after daylighting (b) [9].

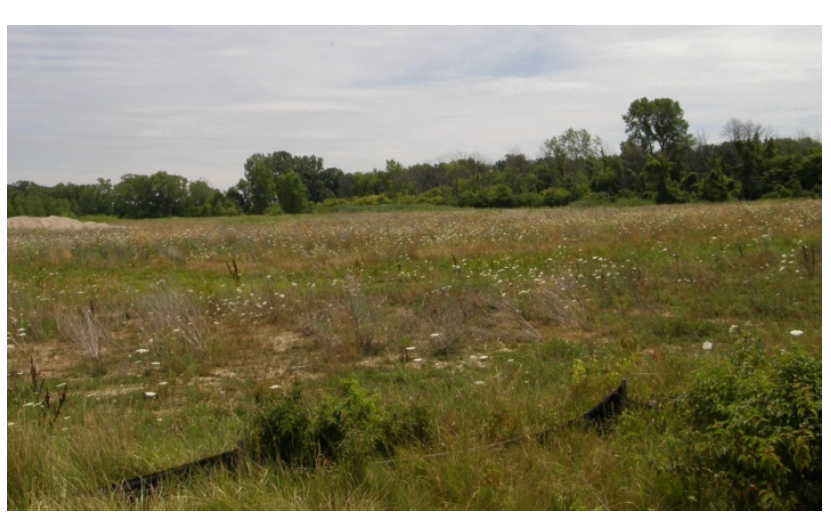

(a)

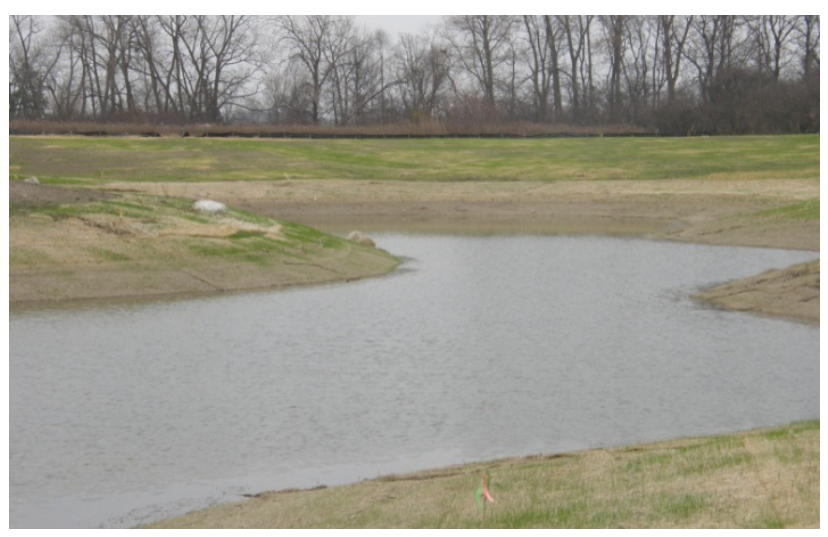

(b)

\subsection{Shoreline Restoration}

Through the historical development of the site for industrial purposes during the 1940s-1960s, approximately $0.25 \mathrm{~km}$ of river bottom and wetlands were filled to support a number of manufacturing operations. At the time of closure of the plant in 1990, the site was relatively flat, with an approximately $3 \mathrm{~m}$ drop at a $90^{\circ}$ angle to the Detroit River. As noted above, the site master plan called for the restoration of a more natural shoreline at the Refuge Gateway. A coastal wetland and habitat restoration plan was then prepared in 2010 by a team of expert scientists, engineers, designers, and representatives from regulatory agencies, accounting for the site environmental constraints. For 
example, the Consent Decree stipulated that five sites totaling approximately 6 ha were subject to restrictive covenants where no digging or excavation could occur. Based on a review of the Baseline Environmental Assessment and other background environmental reports on site contamination by the project team, and analytical testing at randomly selected sampling stations on site, the southeastern portion of the property was selected as the most suitable location for excavation and restoration. This area was outside of any existing restrictive covenants and displayed less intensive industrial development. In an area that has lost an estimated $97 \%$ of historical coastal wetland habitat, this shoreline restoration project would represent a regional net gain of 1.2 ha of this threatened habitat.

In 2011, shoreline restoration began with the removal of $30,600 \mathrm{~m}^{3}$ of fill from the 1.2 ha of land at southeast corner of the property. Through the excavation process it was discovered there was a lens of residual contamination (i.e., primarily petroleum residue) at the old river bottom (4.3-4.6 m below existing grade) that was filled in during the 1940s-1960s. It was the consensus of the project team and environmental experts that the residual contamination discovered was probably historical oil pollution dating back primarily to the $1940 \mathrm{~s}-1960 \mathrm{~s}$.

To avoid exposing residual contamination and creating a direct hydrologic pathway to the Detroit River, and to comply with regulatory agency cleanup standards and shoreline restoration permits, the shoreline restoration design had to be modified consistent with an adaptive management philosophy. The project team, with concurrence from state and federal regulatory agency staff, agreed to limit excavation to $0.6-1.2 \mathrm{~m}$ above the old river bottom (i.e., contaminated lens stratum). A $15 \mathrm{~cm}$ thick layer of clay and $15 \mathrm{~cm}$ layer of topsoil were installed creating a cap over the contaminated material. It should be noted that there was no evidence of residual contaminant movement into the Detroit River.

The project team modified the design plans to construct a coastal wetland shelf along the entire Detroit River shoreline and riparian buffer habitat at the southeastern corner of the site where the residual contamination was discovered. Overland water flow and fluctuating water levels in the Detroit River would maintain seasonal inundation to support a hydrophytic plant community at this southeastern corner. These design changes produced 0.9 ha of coastal wetlands.

No excavated soils were removed from the site. All $30,600 \mathrm{~m}^{3}$ of soils excavated for restoration of wetland and riparian buffer habitat were deemed environmentally-suitable material for capping and then relocated on site to begin capping of the approximately 6 ha subjected to restrictive covenants. Eventually, at least $0.9-1.8 \mathrm{~m}$ of clean fill will be placed on all 6 ha subjected to restrictive covenants to meet human health standards and provide a greater level of protection for wildlife.

\subsection{Additional Unexpected Discoveries}

Throughout all excavation and restoration work completed during 2008-2011, three additional unforeseen environmental challenges were discovered. These included discovering contaminated sediment while building a stream crossing, unearthing an abandoned underground storage tank while building the first access road, and finding seven 208-L drums of solid hazardous waste. In each case, a proper environmental assessment had to be performed to develop a remedy to meet all state and federal cleanup standards. In the case of the contaminated sediment at the stream crossing, all material had to be removed in lined roll-off boxes and disposed of in a Type 2 Landfill off site. In the case of the abandoned underground storage tank, analytical work confirmed no residual contamination and the 
tank was recycled. In the case of the seven 208-L drums of solid hazardous waste, no scientific evidence of leaching was discovered and all had to be removed by environmental response experts from U.S. Environmental Protection Agency and taken to an off-site hazardous waste treatment facility. Clearly, an important lesson was to expect the unexpected and keep focused on the long-term vision articulated in the master plan.

\subsection{Sustainability and Stewardship}

The Detroit River shoreline restoration work was completed in 2011, including construction of the second access road and a kayak landing for public use. Control of invasive species has been underway for four years and will continue in the future to sustain these unique habitats and biodiversity. Also in 2011, funding was secured to complete the remaining capping and upland buffer habitat restoration called for in the master plan. All construction activities for brownfield cleanup and habitat restoration at the Refuge Gateway will be completed in 2012, expanding the ecological buffer for Michigan's only "Wetland of International Importance" and laying the ecological foundation for a visitor center.

William McDonough, an internationally renowned architect and industrial designer who champions sustainability, has offered planners, developers, and community leaders the following challenge:

If design is the signal of human intention, then we must continually ask ourselves-What are our intentions for our children, for the children of all species, for all time? How do we profitably and boldly manifest the best of those intentions?

This challenge was placed before all stakeholders at the beginning of the project and throughout all work. This became part of the vision that has now turned into the reality of sustainable redevelopment of the Refuge Gateway and preservation of Humbug Marsh into a hub for environmental education and sustainability. Literally over two hundred public, private, and nonprofit organizations have made contributions to this effort and the Refuge was singled out as a national leader in public-private partnerships in the 1995 White House Conference on Cooperative Conservation [10]. Stakeholders have been involved in all aspects of this project from the outset, including planning, design, fundraising, implementation, and stewardship. As a result, it is hoped that a sense of ownership and community pride be felt by all stakeholders, which in turn may help grow a sustainability and stewardship ethic for the site and region.

In addition, numerous partnerships have been established to monitor and evaluate both short- and long-term ecological success of this restoration work. Fishery biologists from U.S. Fish and Wildlife Service and Michigan Department of Natural Resources will be assessing the fish habitat restoration aspects. Ornithologists from U.S. Fish and Wildlife Service and Rouge River Bird Observatory will be evaluating the success of bird stopover habitats. Wetland ecologists from Eastern Michigan University and U.S. Fish and Wildlife Service will be tracking wetland response.

\section{Public Access, Use, and Partnerships}

As part of the effort to provide a compelling outdoor educational and recreational experience, and to teach the next generation of conservationists and sustainability entrepreneurs, $4 \mathrm{~km}$ of hiking trails, two wildlife observation decks, a wetland boardwalk, an environmental educational shelter, and unique 
learning stations were constructed in Humbug Marsh in 2007-2009. Additional trails, observation decks, and another greenway extension are called for in the Master plan for the Refuge Gateway; these public amenities will be constructed after all restoration activities are completed.

The project's focus on sustainability is strongly reflected in material choice. For example, the stream crossing, connecting Humbug Marsh to the Refuge Gateway, was built with used utility poles and ash trees killed by the emerald ash borer, universally accessible trails were constructed with recycled crushed concrete, a wildlife observation deck was constructed with reclaimed wood, and the wetland boardwalk was constructed with $100 \%$ recycled plastic wood. As frequently as possible, local materials and contractors are sourced for the project to reduce emissions from travel and to create meaningful ties to the community.

In addition to amenities on site, significant efforts have been made to increase the accessibility to Humbug Marsh and the Refuge Gateway through connection with local trail networks. In 2010, a $2.4 \mathrm{~km}$ perimeter greenway trail was constructed for bicycling, establishing a non-motorized link between the 650-ha Lake Erie Metropark Unit and the Humbug Marsh Unit and Refuge Gateway. The U.S. Fish and Wildlife Service cooperatively manages 316 ha of unique wetlands and uplands at Lake Erie Metropark under a cooperative management agreement. The new section of greenway trail is now part of $80.5 \mathrm{~km}$ of continuous greenway trail in the Downriver area. More information on the Downriver Linked Greenways Initiative can be found online [11].

The Metropolitan Affairs Coalition and many partners developed a Detroit Heritage River Water Trail that features opportunities for kayaking and canoeing. This unique 'blueway' or water-trail was established to both promote close-to-home paddle-based recreational opportunities and ecotourism [12]. For example, in a national survey performed by the Outdoor Industry Foundation [13], it was reported that paddle-based recreation contributes $\$ 36.1$ billion annually to the U.S. economy. As part of the Detroit Heritage River Water Trail, a kayak landing was constructed at the Refuge Gateway in 2011. Such amenities not only enhance ecotourism in the area, but also substantially improve interpretation and environmental education opportunities in the effort to help develop the next generation of conservationists and sustainability entrepreneurs.

Detroit Audubon Society and other birding groups have recorded over 300 species of birds in this region. With many exceptional opportunities for birding in this major metropolitan area (i.e., Detroit, Michigan-Windsor, Ontario), Metropolitan Affairs Coalition [14] and many partners developed a unique "Byways to Flyways" bird driving tour map to promote 27 exceptional birding sites throughout the Windsor-Detroit metropolitan area. Included within these sites are many Important Bird Areas (IBAs) identified by National Audubon Society, two "Wetlands of International Importance" identified under the Ramsar Convention (i.e., Point Pelee National Park in Ontario and Humbug Marsh in Michigan), several Christmas Bird Count sites, and two internationally recognized hawk migration sites. These world-class birding opportunities are available within a 45-minute drive of nearly seven million people and help support a growing ecotourism industry that brings in millions of dollars to the regional economy [15]. 


\section{Concluding Thoughts and Lessons Learned}

Innovative public-private partnerships are delivering substantial conservation and restoration successes in the DRIWR. One good example is the environmental cleanup and restoration of habitats at an 18-ha industrial brownfield that is literally expanding the ecological buffer for Michigan's only "Wetland of International Importance" (i.e., Humbug Marsh). This site has become the gateway to the DRIWR and will be future home of the Refuge's visitor center.

This project has resulted in: a net gain of 6.5 ha of wetlands in an area that has 10 st $97 \%$ of its coastal wetlands to development; restoration of 10.1 ha of upland buffer habitat; control of invasive plant species on 20.2 ha of upland habitats; and control of invasive Phragmites along $4 \mathrm{~km}$ of shoreline. This has resulted in merging the 18-ha Refuge Gateway with the 166-ha Humbug Marsh into one ecological unit and is helping create an exceptional outdoor recreational and environmental educational experience for nearly seven million people within a 45-minute drive. Much can be learned from this transformation of an industrial brownfield into an ecological buffer for Michigan's only "Wetland of International Importance." Indeed, the following lessons learned from this project could serve as a good starting point and catalyst for similar brownfield cleanup and habitat restoration projects throughout the world:

- reach broad-based agreement on a long-term sustainability vision founded on a sense of place (i.e., a characteristic held by people that makes a place special or unique and that fosters a sense of authentic human attachment and belonging);

- identify a key champion who is well recognized throughout the region, is trusted, and can open doors, help bring in partners, and build capacity;

- $\quad$ establish a core project delivery team;

- $\quad$ ensure all regulatory agencies are involved up front in the process to ensure buy-in, support for project, and timely review and approval of permits;

- $\quad$ recruit and inspire partners to get involved in all aspects of the project (e.g., building a native plant entry garden, planting trees, removing invasive species, etc.), founded on cooperative learning and action;

- $\quad$ expect the unexpected and keep focused on the long-term vision;

- use an adaptive management process that assesses problems and opportunities, sets priorities, and takes actions in an iterative fashion for continuous improvement is essential;

- place a priority on sound science-based decision making that can result in more cost- and ecosystem effective actions;

- ensure transparency in the decision-making process;

- measure and celebrate successes throughout the process to sustain project momentum;

- quantify benefits and manifest them to attract new partners and help retain existing ones; and

- place a high priority on education and outreach to help develop the next generation of conservationists and sustainability entrepreneurs.

\section{Conflict of Interest}

The authors declare no conflict of interest. 


\section{Disclaimer}

The findings and conclusions in this article are those of the authors and do not necessarily represent the views of the U.S. Fish and Wildlife Service.

\section{References}

1. U.S. Fish and Wildlife Service. Comprehensive Conservation Plan and Environmental Assessment for the Detroit River International Wildlife Refuge; U.S. Fish and Wildlife Service: Grosse Ile, MI, USA, 2005. Available online: www.fws.gov/midwest/planning/detroitriver/ (accessed on 27 January 2012).

2. U.S. Fish and Wildlife Service and International Wildlife Refuge Alliance. Building Our Refuge: Detroit River International Wildlife Refuge; U.S. Fish and Wildlife Service and International Wildlife Refuge Alliance: Grosse Ile, MI, USA, 2008.

3. Ramsar Convention Secretariat. The Ramsar Convention Manual: A guide to the Convention on Wetlands (Ramsar, Iran, 1971), 5th ed.; Ramsar Convention Secretariat: Gland, Switzerland, 2011. Available online: http://www.ramsar.org/cda/en/ramsar-pubs-manual-manual5/main/ ramsar/1-30-35\%5E25489_4000_0__ (accessed on 27 January 2012).

4. Metropolitan Affairs Coalition. A Conservation Vision for the Lower Detroit River Ecosystem; Metropolitan Affairs Coalition: Detroit, Michigan, USA, 2001. Available online: www.fws.gov/ midwest/detroitriver/documents/ahrconservation.pdf (accessed on 27 January 2012).

5. Stell, C. Administrative Order of Consent, Covenants Not to Sue and Contribution Protection; Michigan Circuit Court of the County of Ingham: Lansing, MI, USA, 1994.

6. U.S. Fish and Wildlife Service and International Wildlife Refuge Alliance. Building Our International Wildlife Refuge in the Industrial Heartland; U.S. Fish and Wildlife Service and International Wildlife Refuge Alliance: Grosse Ile, MI, USA, 2005.

7. U.S. Fish and Wildlife Service. Why Humbug Marsh?; U.S. Fish and Wildlife Service: Grosse Ile, MI, USA, 2011. Available online: http://www.fws.gov/midwest/detroitriver/ HumbugWhy.html (accessed on 27 January 2012).

8. Hamilton Anderson Associates. Refuge Gateway Master Plan; Hamilton Anderson Associates: Detroit, MI, USA, 2004.

9. U.S. Fish and Wildlife Service. Photographs of Refuge Gateway Before and After Daylighting; U.S. Fish and Wildlife Service: Grosse Ile, MI, USA, 2011.

10. Council on Environmental Quality. Proceedings of the White House Conference on Cooperative Conservation; Council on Environmental Quality: St. Louis, Missouri, USA, 2005. Available online: http://cooperativeconservation.gov/contact.html (accessed on 27 January 2012).

11. Downriver Linked Greenways Initiative. Available online: www.downrivergreenways.org (accessed on 27 January 2012).

12. Metropolitan Affairs Coalition. Detroit Heritage River Water Trail; Metropolitan Affairs Coalition: Detroit, Michigan, USA, 2006. Available online: www.mac-web.org/Projects/ HeritageWaterTrail.htm (accessed on 27 January 2012). 
13. Outdoor Industry Foundation. The Active Outdoor Recreation Economy; Outdoor Industry Foundation: Boulder, Colorado, USA, 2006. Available online: www.outdoorfoundation.org/ pdf/ResearchRecreationEconomy.pdf (accessed on 27 January 2012).

14. Metropolitan Affairs Coalition. Byways to Flyways: A Driving Tour of Featured Birding Locations in the Windsor-Detroit Metropolitan Area; Metropolitan Affairs Coalition: Detroit, Michigan, USA, 2007. Available online: www.mac-web.org/Projects/ DiscoverOurWildSide/BywaysToFlyways.htm (accessed on 27 January 2012).

15. U.S. Department of the Interior, Fish and Wildlife Service, and U.S. Department of Commerce. 2006 National Survey of Fishing, Hunting, and Wildlife-Associated Recreation; U.S. Department of the Interior, Fish and Wildlife Service, and U.S. Department of Commerce: Washington, DC, USA, 2006.

(C) 2012 by the authors; licensee MDPI, Basel, Switzerland. This article is an open access article distributed under the terms and conditions of the Creative Commons Attribution license (http://creativecommons.org/licenses/by/3.0/). 